\title{
Evaluation of effects of supplementation of sun-dried leaves of mucuna poggei on the growth and carcass characteristics of broiler birds
}

\author{
Oko A. O.", Afiukwa, C. A., Ali F. U., Ahamefule K. A., Ezeonu, A. O., Nwoba S. T. \\ Department of Biotechnology, Ebonyi State University, P.M.B. 053 Abakaliki, Ebonyi State, Nigeria \\ Email address: \\ okpanioko@gmail.com(Oko A. O.) \\ To cite this article: \\ Oko A. O., Afiukwa, C. A., Ali F. U., Ahamefule K. A., Ezeonu, O. A., Nwoba S. T.. Evaluation of Effects of Supplementation of Sun- \\ Dried Leaves of Mucuna Poggei on the Growth and Carcass Characteristics of Birds. American Journal of Life Sciences. \\ Vol. 1, No. 3, 2013, pp. 82-87. doi: 10.11648/j.ajls.20130103.11
}

\begin{abstract}
An eight week evaluation of the effects of supplementation of sun dried leaves of Mucuna poggei on the growth and carcass characteristics of broiler birds was carried out. Forty broiler birds (a day old) were grouped into four (10 birds each). The feed of groups A, B and C were supplemented with $20 \mathrm{~g}, 30 \mathrm{~g}$ and $40 \mathrm{~g}$ of sun-dried leaves of Mucuna poggei respectively, while group D served as control. The weights of the broilers were taken three times in a week and their average weekly weights were obtained. At the end of the eighth week, the birds were euthanized and weight of different body parts taken to determine the quality of their meat and the characteristics their carcasses. The breast meats were used for drip and cooking loss determination. Results showed that the feed conversions as well as the growth rate of group B birds were the best, having a highest mean live-weight of $1797.67 \pm 7.37 \mathrm{~g}$. The group also had the most superior carcass characteristics and a few other qualities studied. This was followed by group A with a mean live-weight of $1700.50 \pm 4.20 \mathrm{~g}$, followed by group C $(1550.67 \pm 6.03 \mathrm{~g})$ while group D (Control) had the least growth and mean live-weight of 1327.50 \pm 3.54 g. Statistical analysis revealed significant differences $(\mathrm{P}<0.05)$ between group $\mathrm{B}$ and others. The implication is that at $30 \mathrm{~g}$ daily supplementation rate, sun dried leaves of Mucuna poggei could be used to enhance the growth rate and carcass characteristics of birds with no deleterious effects. Also, leaves of Mucuna poggei could be sundried and used during the dry season. However there is need to subject Mucuna poggei leaves to processing methods that can reduce the antinutrients contents for more efficient utilization of its nutrients in broiler birds.
\end{abstract}

Keywords: Birds, Sun-Dried Leaves, Mucuna Poggei, Carcass, Growth, Feeds, Drip and Cooking Loss

\section{Introduction}

Birds are raised basically for either meat or egg production. The meat producing birds are called broilers and they are raised specifically on litter such as wood shavings or rice husks, usually indoors under a climate controlled house. Modern commercial broilers grow much faster than egg and dual-purpose birds. They are characterized by fast growth, high feed conversion ratio, and low level of activity. Broiler birds often reach weights of 4-5 pounds within five weeks (Hill and Dansky, 2005). The growth rate of broilers depend on some factors which include among others; the species, rearing method, disease control measures adopted while rearing them, the quality of feed used etc (Hill and Dansky, 2005).

There has been continous scarcity and high cost of rearing birds in West Africa, making cost of production of the livestock high. Cost of feed is the most important single factor militating against profit-making among poultry farmers in Nigeria. It has been reported that poultry feeds account for about $70-80 \%$ of the total cost of poultry production (Olomu, 1979 and Oko et al., 2012). According to Afolabi et al., (2005), a great percentage of this feed cost arises from providing adequate energy source in form of grains. The high cost of feeds has been attributed to its scarcity and difficulty in sourcing major nutrients locally. This scarcity is also caused by inadequate knowledge of possible and cheaper sources of feed ingredients, lack of information on the use of agro-industrial products, over dependence on the importation of certain feed items that has local substitute etc (Olaboro, et al., 2001 and Oko et al, 2012) 
The research for new feed stuffs for livestock rations in general and poultry (birds) in particular to reduce the soaring cost of commercial feed and consequently reduce the high cost of raising chickens is obviously necessary and imperative. This can be achieved by incorporating into feeds, cheaper nutrient sources which do not qualify for direct human consumption (Hill and Dansky, 2005). Some of such substitutes include; cassava peels, rice husks, ground maize chaff, local mineral sources etc. In addition, it has been observed that some underutilized legumes promote the growth performance and many other essential characteristics in birds, chief among which is Mucuna poggei. The leaves of Mucuna poggei has interesting and substantial composition of nutrients such as calories, proteins, vitamins and minerals that are critical to the growth of birds (Oko et al, 2012) and (Awosanya et al., 1999).

Mucuna is a genus of around 100 accepted species of climbing vines and shrubs of the family Fabaceae, found in the woodlands of tropical areas. The leaves are 3-palmate, alternate or spiraled, and the flowers are pea-like but larger with distinctive curved petals and occure in racemes. Like other legumes, Mucuna plants bear pods. They are generally bat-pollinated and produce seeds that are buoyant sea-beans.

Mucuna poggei is a tropical legume known as co-witch and by other different local names. They are found in Africa, India and the Caribbean. The plant is famous for its extreme itchiness produced on contact with human body, particularly with its young foliages and seed pods. It has both agricultural and horticultural values and has a range of medicinal properties. Mucuna poggei leaves represent an interesting potential food and feed commodity because of its nutritional contents.

Many scholars have unravelled the advantageous effects of incorporating the leaves into the diets of poultry (Cilly et al., 2003 and Oko et al, 2012), and an outstanding noticeable differences have been found in the growth performance and carcass qualities of broilers fed with adequate amount of Mucuna poggei leaves without multivitamin supplements than others fed with conventional commercial feed (Odunsi and Olomu, 2000).

Emenalom and Udedibie, (2005) determined the nutritional composition of the leaves and thus discovered the potentials of this underutilized legume in nutrition. The leaves were analyzed for their proximate, mineral, some anti-nutritive factors and toxic metals compositions. Interestingly, Mucuna poggei leaves can supplement the recommended dietary intake (RDI) of $\mathrm{Fe}, \mathrm{Ca}$ and $\mathrm{Cu}$ given their quantity in the leaves.

From the foregoing, it is evident that Mucuna poggei has good nutrient potentials which could be harnessed and utilized in poultry production. This research is therefore aimed among other things to determine the effects of sundried leaves of Mucuna poggei on the growth and carcass characteristics of poultry birds, hence the possibility of preserving them for use during the dry seasons when they are usually in short supply.

\section{Materials and Method}

\subsection{Housing/Site of the Study}

The research was conducted at Abakaliki in Ebonyi State (Eastern Nigeria), found to be relatively hot (about $27^{\circ} \mathrm{C}$ $34^{\circ} \mathrm{C}$ ) during the day. Day old poultry birds (forty in number) were bought at a commercial poultry farm in Enugu, Enugu state, Nigeria. The birds were housed in a concrete floored pen; the floor was covered with wood shavings (saw-dust) as the litter material. The chicks were shared into four groups of 10 each and reared for eight weeks. The demarcation of the individual group was done using wire-gauze, with each pen measuring 3 by 4 feet.

\subsection{Experimental Diet/Method of Feeding}

Mucuna poggei leaves used for this study were harvested in a local farmland in Abakaliki. The leaves were dried in the sun and ground with the help of a blender. The ground leaves were incorporated into the birds' feed. The birds were allowed to acclimatize for two week, during which time they were fed with conventional feeds without any suplement. The feeding of the birds with the Mucuna poggei leaves commenced after the two weeks acclimatization period. The supplementation rate of the leaves for the various groups were as follows: $0 \mathrm{~g}$ for group D (control), 20g, 30g, and 40g for groups A, B, and C respectively and they were fed with the leaves thrice daily. The required measurement of the dried leaves for each group was taken and then mixed with moderate quantities of the feed to ensure complete utilization. The birds in all the groups were adequately fed in that order throughout the experiment. Water was made availble for all the birds on 24-hour basis daily. During the first five weeks of the experiment, antibiotics and oral vaccines were added in the drinkers at the inclusion rate of $2.5 \mathrm{~g}$ for each of them. This was to maintain the birds' good health and boost their immunity. After the fifth week, the use of vaccines was stopped following the recommendation of the manufacturer. Howeverr, antibiotics were used throughout the experiment.

\subsection{Weighing of the Birds}

The individual live weights of the birds were taken three times weekly throughout the experiment. The weights were taken with a $5 \mathrm{~kg}$ maximum scale and the records gotten were used for further analysis as in the work.

\subsection{Hygiene/Cleaning}

The four pens comprising different groups were swept together with the immediate environment at least thrice in a week. After each clean-up, the area was disinfected before new saw-dusts were spread. Also, the feeding troughs and drinkers were washed with detergents each time the place was swept. 


\subsection{Carcass and Organ Weight Evaluation}

At the end of the eighth week, the birds were subjected to an overnight fasting (to get the real body weight), after which they were weighed and euthanized by cutting off the jugular veins. This was to ensure that the neck bones were intact. The carcasses were scalded in warm water of about ninety degrees celcius and the feathers were manually plucked, cleaned, dissected and eviscerated. The head and legs were cut at atlanto-occipital and tibio-metatarsus joints respectively. The weights of the carcasses heads, legs, hearts, livers and gizzards were obtained. Carcasses were preserved in deep freezer at four degree celcius for 24 hours and reweighed for gross changes inspection. Other body parts like; breasts, thigh-drumsticks, wings, necks and back-cuts were carved out of the carcasses and their weights were determined.

\subsection{Drip and Cooking Loss Determination}

After carving out breast samples of about $100 \mathrm{~g}$, they were used for drip and cooking loss determination. Meat samples were inserted into polyethene bags freely hung with the help of wooden hooks and maintained at a temperature lower than the room temperature (to reduce evaporation) for 48 hours. Samples were then removed, mopped up with wool towel and weighed for drip-loss determination. Samples were placed in a hot water and allowed for 30 minutes, cooled to room temperature and reweighed to get the weight the difference in weight before and after cooking which gives the cooking loss. In the drip loss determination, the meat samples were refrigerated to ensure that they were exposed to an environment where evaporation is minimal. This was geared towards obtaining the real drip loss values because it prevented the anomaly that would have occurred in the presence of evaporation.

\subsection{Statistical Analysis}

All data obtained were analyzed using Analysis of Variance (ANOVA) procedure using SAS software (SAS Institute, 1999). Differences were declared statistically significant at $\mathrm{P} \leq 0.05$. Where significant differences were detected, the means were separated by Least Significant Difference (LSD) at 5\% probability.

\section{Results}

\subsection{Variation in Weekly Live-weights of the Birds}

Table 1 shows the effects of the dried leaves Mucuna poggei supplement on the live weight development of the broiler birds. The results revealed some level of significant differences among the treatment mean values as the number of weeks increased. At the eighth week, birds placed on $30 \mathrm{~g}$ supplementation rate (group B) had the highest mean liveweight of $1797.67 \pm 7.37$, followed by the ones that had $20 \mathrm{~g}$ supplementation rate (group A) with mean live-weight of $1700.50 \pm 4.20 \mathrm{~g}$ and then followed by the ones that had $50 \mathrm{~g}$ supplementation rate (group $\mathrm{C}$ ) which had a mean liveweight of $1550.67 \pm 6.0 \mathrm{~g}$. However, birds placed on $0 \mathrm{~g}$ supplementation rate (the control) had the least mean weight value of $1297.50 \pm 3.54 \mathrm{~g}$.

Table 1. Mean Weekly Live Weights (g) of Broilers Groups with Different Levels of Diet Supplementation

\begin{tabular}{cccc}
\hline Week & A & B & C \\
\hline $1^{\text {st }}$ & $318.75 \pm 2.99$ & $320.75 \pm 2.99$ & $316.25 \pm 2.99$ \\
$2^{\text {nd }}$ & $515.00 \pm 4.08$ & $481.00 \pm 97.33$ & $457.00 \pm 21.01$ \\
$3^{\text {rd }}$ & $704.75 \pm 3.69$ & $740.75 \pm 3.20$ & $685.50 \pm 4.12$ \\
$4^{\text {th }}$ & $907.00 \pm 6.27$ & $954.25 \pm 4.19$ & $851.00 \pm 2.94$ \\
$5^{\text {th }}$ & $1104.75 \pm 4.11$ & $1164.25 \pm 4.35$ & $992.25 \pm 2.06$ \\
$6^{\text {th }}$ & $1316.75 \pm 15.56$ & $1374.00 \pm 4.32$ & $1222.25 \pm 2.06$ \\
$7^{\text {th }}$ & $1497.50 \pm 2.08$ & $1585.00 \pm 5.35$ & $1381.33 \pm 1.53$ \\
$8^{\text {th }}$ & $1700.50 \pm 4.20$ & $1797.67 \pm 7.37$ & $1550.67 \pm 6.03$ \\
Mean $^{\text {Prob. }}$ & $1008.13 \pm 5.37$ & $1052.13 \pm 16.14$ & $93.39 \pm 2.52$ \\
\end{tabular}

*Means with the same letter are not significantly different from each other at $\mathrm{P}<0.05$.

Table 2. The Mean Weight ( $g$ ) of the Carcasses and Feathers

\begin{tabular}{|c|c|c|c|c|c|c|c|}
\hline Group & $\mathrm{A}$ & $\mathrm{B}$ & $\mathrm{C}$ & $\mathrm{D}$ & MEAN & PROB & $\mathrm{LSD}_{0.05}$ \\
\hline Feathers Weight & $127.00 \pm 2.00^{\mathrm{a}}$ & $109.00 \pm 1.00^{\mathrm{b}}$ & $104.67 \pm 1.53^{\mathrm{c}}$ & $98.67 \pm 1.53^{d}$ & 109.83 & $<.0001$ & 2.93 \\
\hline Carcass Weight & $1596.67 \pm 5.77^{\mathrm{a}}$ & $1696.67 \pm 5.77^{\mathrm{b}}$ & $1370.33 \pm 3.51^{\mathrm{c}}$ & $1200.00 \pm 1.53^{\mathrm{d}}$ & 1465.92 & $<.0001$ & 8.37 \\
\hline
\end{tabular}

*Mean with a different letter significantly differs from others at $\mathrm{P} \leq 0.05$.

\subsection{Mean Weight of the Carcasses Before and after Removal of Feathers}

Table 2 above shows the net weight loss after the removal of feathers from the birds' carcasses. Statistical anylysis revealed highly significant differences $(<.0001)$ among individual groups. However the net weight loss in group A which is $127.00 \pm 2.00$, is more than that of group B $(109.00 \pm 1.00)$, unlike the values of their live weights, but group D had the least net weight loss of $98.67 \pm 1.53$ as expected. 


\subsection{Mean Weight Gain of Organs after Preservation at Four Degree Celcius for 24 Hours}

The results of the variation in weights of some body parts/ organs after preservation are contained in table 3 . In terms of within group comparison of different parts/organs, there were significant differences $(\mathrm{P}<0.05)$ in some. This was different in the case of the liver, gizzard and drumstick which did not differ significantly except for groups $\mathrm{C}$ and $\mathrm{D}$ where different observations were made. Groups A and $\mathrm{B}$ (which performed better in live weights) differed significantly $(\mathrm{P}<0.05)$ from groups $\mathrm{C}$ and $\mathrm{D}$ except for parts/organs like gizzard, complete leg, and drum-stick that showed no differences (had the same letter b).

Table 3. Weights (g) of other Body Parts Measured after Preservation.

\begin{tabular}{|c|c|c|c|c|}
\hline Group & A & B & $\mathrm{C}$ & D \\
\hline Breast & $173.33 \pm 1.53^{b}$ & $201.00 \pm 1.73^{\mathrm{b}}$ & $162.67 \pm 3.79^{b}$ & $149.67 \pm 0.58^{b}$ \\
\hline Back-cut & $238.33 \pm 16.07^{\mathrm{a}}$ & $283.33 \pm 57.95^{\mathrm{a}}$ & $242.67 \pm 2.52^{\mathrm{a}}$ & $201.33 \pm 2.31^{\mathrm{a}}$ \\
\hline Neck & $82.333 \pm 2.08^{c}$ & $100.00 \pm 0.00^{c}$ & $72.33 \pm 2.52^{\mathrm{c}}$ & $61.67 \pm 2.89^{c}$ \\
\hline Wing & $73.00 \pm 2.65^{c}$ & $101.67 \pm 2.89^{c}$ & $72.00 \pm 3.46^{\mathrm{c}}$ & $56.67 \pm 2.08^{d}$ \\
\hline MEAN & 141.75 & 171.50 & 137.42 & 117.33 \\
\hline PROB & $<.0001$ & 0.0001 & $<.0001$ & $<.0001$ \\
\hline $\mathrm{LSD}_{0.05}$ & 15.53 & 54.65 & 5.88 & 4.03 \\
\hline
\end{tabular}

*Means with the same letter are not significantly different from each other at $\mathrm{P}<0.05$.

\subsection{Weights of other Body Parts Measured after Preservation}

Table 4 below shows the mean variation in the weights of some body parts of the broiler birds. There were high significant differences $(\mathrm{P}<0.0001)$ within each group, but not so between groups, where no significant difference existed at $\mathrm{P}>0.0001$. The highest breast mean weight

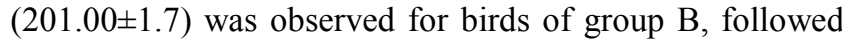
by groups $\mathrm{A}, \mathrm{C}$ and then $\mathrm{D}$.

Table 4. Mean Weight Gain (g) of Body Parts/Organs after Preservation at $4^{\circ} \mathrm{C}$ for 24 Hours.

\begin{tabular}{ccccc}
\hline Groups & A & B & C & D \\
\hline Heart & $5.33 \pm 1.53^{\mathrm{d}}$ & $7.00 \pm 1.00^{\mathrm{d}}$ & $4.00 \pm 1.00^{\mathrm{e}}$ & $4.00 \pm 1.00^{\mathrm{d}}$ \\
Liver & $22.67 \pm 2.52^{\mathrm{b}}$ & $23.00 \pm 3.61^{\mathrm{b}}$ & $11.00 \pm 1.00^{\mathrm{c}}$ & $12.00 \pm 2.00^{\mathrm{c}}$ \\
Gizzard & $21.67 \pm 2.08^{\mathrm{b}}$ & $24.67 \pm 1.53^{\mathrm{b}}$ & $15.00 \pm 2.00^{\mathrm{b}}$ & $15.00 \pm 2.00^{\mathrm{b}}$ \\
Head & $6.00 \pm 1.00^{\mathrm{d}}$ & $17.67 \pm 1.53^{\mathrm{c}}$ & $4.67 \pm 0.58^{\mathrm{d}}$ & $4.67 \pm 1.53^{\mathrm{d}}$ \\
Tibia & $12.002 .65^{\mathrm{c}}$ & $13.67 \pm 3.21^{\mathrm{c}}$ & $7.00 \pm 1.00^{\mathrm{d}}$ & $4.00 \pm 1.00^{\mathrm{d}}$ \\
Complete leg & $32.33 \pm 2.52^{\mathrm{a}}$ & $33.33 \pm 2.89^{\mathrm{a}}$ & $22.67 \pm 2.52^{\mathrm{a}}$ & $23.00 \pm 2.65^{\mathrm{a}}$ \\
Drum Stick & $22.67 \pm 2.52^{\mathrm{b}}$ & $22.67 \pm 2.52^{\mathrm{b}}$ & $17.67 \pm 2.52^{\mathrm{b}}$ & $15.33 \pm 1.52^{\mathrm{b}}$ \\
MEAN & 17.52 & 20.29 & 11.71 & 11.12 \\
PROB & $<.0001$ & $<.0001$ & $<.0001$ & $<.0001$ \\
LSD $_{0.05}$ & 3.84 & 4.37 & 2.96 & 3.08 \\
\hline
\end{tabular}

*Means with the same letter are not significantly different from each other at $\mathrm{P}<0.05$.

Table 5. The Mean Cooking and Drip Loss of Breast Meat of Broilers

\begin{tabular}{|c|c|c|c|c|}
\hline & $\mathrm{A}$ & $\mathrm{B}$ & $\mathrm{C}$ & $\mathrm{D}$ \\
\hline Cooking Loss & $22.67 \pm 2.52^{\mathrm{a}}$ & $20.00 \pm 2.00^{\mathrm{a}}$ & $21.67 \pm 1.53^{\mathrm{a}}$ & $25.33 \pm 1.53^{\mathrm{b}}$ \\
\hline Drip Loss & $23.67 \pm 2.51^{\mathrm{a}}$ & $23.00 \pm 2.65^{\mathrm{a}}$ & $23.00 \pm 5.20^{\mathrm{a}}$ & $23.00 \pm 3.00^{\mathrm{a}}$ \\
\hline MEAN & 23.17 & 21.50 & 22.33 & 24.17 \\
\hline PROB & 0.07 & 0.11 & 0.69 & 0.03 \\
\hline $\mathrm{LSD}_{0.05}$ & 5.71 & 5.32 & 8.68 & 5.40 \\
\hline
\end{tabular}

*Means with the same letter are not significantly different from each other at $\mathrm{P}<0.05$.

\subsection{Cooking and Drip Losses of the Breasts Meat}

The result of the cooking and drip losses of the breast meats showed that there was a relationship between the two parameters. The analysis of variance showed no significant difference for drip loss, as all of them had the same letter "a". However, results of the cooking loss for groups A, B and $\mathrm{C}$ were not statistically different $\left(22.67 \pm 2.52^{\mathrm{a}}\right.$, $20.00 \pm 2.00^{\mathrm{a}}$, and $21.67 \pm 1.53^{\mathrm{a}}$ respectively) but varied significantly from group D $\left(25.33 \pm 1.53^{\mathrm{b}}\right)$.

\section{Discussion}

The result of the study presented in table 1 and 2 revealed that significant differences $(p<0.0001)$ existed among the mean live-weights and carcasses weights of the birds. The group B fed with $30 \mathrm{~g}$ of the dried leaves supplement had the highest mean live-weight, followed by 
the group A fed with $20 \mathrm{~g}$ of the extract and then followed by the group $\mathrm{C}$ while the group $\mathrm{D}$ (control) had the least live-weight. This indicate that at a moderate supplementation of sun-dried leaves of Mucuna poggei broiler birds grew fastest, but experiences retarded growth and low weight gain when fed with much of the dried leaves but not as poor as when they were given no supplement of the sun-dried leaves. The birds' carcasses also showed similar characteristics in terms of sizes and weights. These show that there is correlation between the live-weights of the birds and the weights of their carcasses as reported by Oko et al., (2012). The low live-weight and low carcasses weight gained by the group $\mathrm{C}$ that consumed the highest quantity of sun-dried leaves of Mucuna poggei could be attributed to their higher consumption of antinutrient factors such as phytate, saponin, alkaloids, tanin, L-Dopa, hydrogen cyanide, trypsin inhibitors etc present in the leaves as reported by Oko et al., (2012). Phytate is an anti-nutrient known to increase mineral requirement in animals by forming complexes with minerals. Also, prolonged intake of hydrogen cyanide damages the central nervous system and the thyroid and cause poor growth in animals while trypsin inhibitors inhibit protein consumption in animals (Makkar and Becker, 1997). The group A and B must have had higher live-weights and bigger sizes because of the lower quantity of the antinutrient factors in their daily ration. As a result the broiler birds in the two groups had much efficient utilization of the nutrients in their feed rations. In addition the relative high quantity of protein and calories reported in some Mucuna species by Ihedioha and Okoye, (2011), must have been responsible for the better performance of the broiler birds fed with the sun-dried leaves supplement than the group D that were not fed with the sun-dried leaves; this reveals the indispensable nutritional content of the Mucuna poggei leaves. This is in line with the report of Cilly et al., (2003) which stated that at certain inclusion level, extracts from Mucuna poggei enhance broiler performances better.

Tables 3 and 4 revealed significant differences $(\mathrm{P} \leq 0.05)$ that existed among the birds of different groups, especially for organs like the heart and liver. This is an indication that the sun-dried leaves affected the sizes of such organs, as opposed by Afolabi et al., (2005), who claimed that there is no such impact in organs. Cilly et al., (2003) noted that increment in internal organs entails better functionality. However, the parameters of table 4 did not differ, except for the wing of the control that is significantly smaller $(\mathrm{P}<0.05)$ than others, certainly due to its least live-weight. The gain in weight of body parts after refrigeration was as a result of moisture absorption which depended on the general surface area and meat characteristics of the broiler birds as earlier reported by Odunsi and Olomu (2000). Consequently, the group B broiler birds which performed better than others in live-weight had more surface area; followed by the group $\mathrm{C}$ and then group A which had the least live-weight also had the least surface area. Therefore there is a relationship between the size of surface area of the meat and the initial live-weight of the birds. This is as a result of the effects of the sun-dried leaves supplement on the birds.

The drip and cooking loss results revealed that sun dried Mucuna poggei leaves reduce the cooking loss of meat, just as Looft et al., (2004) reported in their work. However, unlike the view of Looft et al., (2004), statistical result did not revealed any significant differences $(\mathrm{P} \leq 0.05)$ among the mean drip losses of the birds in the four groups, an indication that the leaves had minimal effect on the parameter. However, since the water holding capacity (WHC) measures the fraction of bound water retained in the muscle, group B samples with the lowest percentages of drip and cooking losses had the highest WHC, and thus its meat is considered of a better quality, since the lower the water holding capacity the better the meat quality (Navid et al., 2010). In the same vein, the low cooking loss of the breast meat of broiler birds fed with sun-dried leaves of Mucuna poggei indicated that the meat is of high quality due to low loss of protein into the water during cooking. Proteins are lost into the water due to proteolysis. Proteolysis is low in tougher meats with lower fat content. This agrees with Oko et al., 2012, that had earlier reported that meat with low cook loss has higher quality and protein content.

Group C (the group with the highest level of supplementation rate of the leaves) performed lower than groups A and B, but of course better than the control. This could be attributed to the effects of anti-nutritional factors contained in Mucuna poggei, which reduces the absorption of the rich nutrients contained in the leaves, as reported by Emenalom and Udedibie, (2005). This is also in line with the observation made by Uchegbu, et al., (2002) in their experiment. They stated that these anti-nutritional factors which include trypsin inhibitors, lectins, phytates, phenols, cyanogenic glycosides, alpha amylase inhibitors, tannins, L-3,4-dihydroxyphenylalanine (L-dopa), among others affect its acceptability and utilization by ruminant animals (birds inclusive) at certain inclusion level depending on the degree of processing.

\section{Conclusion}

This research work established the fact that $30 \mathrm{~g}$ of sundried leaves of Mucuna poggei given to ten broiler birds in a day increased the WHC of the poultry's meat. Any increase in WHC is an indication of increased juiciness and general improvement of meat quality. It was also observed that sun-dried leaves of Mucuna poggei could be used in poultry diets to enhance certain performance like liveweight, growth rate, carcass characteristics, drip loss and cooking loss. It is also observed that sun-dried leaves of Mucuna poggei is potent enough to be used as feed supplement in poultry rearing. However, we suggest that further research is necessary to determine how to increase the nutritive value of Mucuna poggei leaves for use as dietary supplement in poultry farming, in view of its relative abundance and ease of collection in this part of the 
world. Also improved processing and storing methods should be adopted to accelerate the assimilation of the nutrients as dietary supplements by poultry birds. We therefore recommend the moderate incorporation of ground sun-dried leaves of Mucuna poggei in feeds of poultry birds owing to its huge positive effects on the their growth and improved carcass characteristics and meat qualities. Therefore, the leaves could be gathered during the rainy season when they are usually abundant and sun-dry them for use during the dry season when they are usually in short supply.

\section{References}

[1] Afolabi, O. A., Oshuntogun, B. A., Adewesi, S. R., Fapojuwo, O. O., Grissom, F. E., and Oke, O. L. (2005). Preliminary Nutritional and Chemical Evaluation of Raw Leaves from Mucuna poggei. Journal of Agricultural and Food Chemistry, 33, 122-124.

[2] Awosanya, B., Joseph, J. K., Apata, D.F. and Ayoola, M. A. (1999). Performance, Blood Chemistry and Carcass Quality Attributes of Birds fed Raw and Processed Prueraria Seed Meal. Tropical Journal of Animal Science, 2 (2): 89-96

[3] Cilly, V. K., Lodhi, G. N. and Ichponani, J. S. (2003). Effect of Different Levels of Protein and Energy on the Perfomance of Starter Chicks. Indian Journal of Animal Science, 45 (5): 408-416.

[4] Emenalom, O. O. and Udedibie, A. B. (2005). Effect of Dietary Raw, Sun-dried and Roasted Mucuna poggei Leaves on the Performance of Finisher Broilers. Nigerian Journal of Animal Production, 25 (2): 115-119.

[5] Hill, F. W. and Dansky, L. M. (2005). Studies on the Energy Requirements of Chicks. Poultry Science Journal, 33, 10341041.

[6] Ihedioha, C.N. and Okoye, C.O. (2011). Nutritional Evaluation of Munua flageillipes leaves: An underutilized Legume in Eastern Nigeria. American Journal of Plant Nutrition and Fertilization, 1, 55-63.
[7] Looft, H., Otto, G., Roche, R., Thoelking, L. and Kaim, E. (2004). Comparison of Different Methods of Drip and Cooking Loss Determination and their Relationship to Meat Quality and Carcass Characteristics in Broilers. Meat Science Journal, 68 (3): 401-409.

[8] Makkar, H.P. and Becker, K. (1997). Nutrient and Antinutrient factors in Morphological parts of the Moringa oleifere tree. Cambridge Journal of Agricultural Science, $128,311-322$.

[9] Navid, S., Hilmi, M., Sazili, A. Q. and Sheikhlar, A. (2010). Effect of Papaya Leaf Meal and Vitamin D3 Supplementation on Meat Quality of Spent Layer Hen. Journal of Animal and Veterinary Advances, 9 (22): 28732876.

[10] Odunsi, A. A. and Olomu, J. A. (2000). Growth, Carcass Characteristics and Body Composition of Broiler Chicken fed Wild Sunflower (Tithonia diversifolia) forage meal. Tropical Animal Production and Investigation Journal, 2, 205-211.

[11] Oko, A.O., Nwoba, S.T., Idenyi, J.N., Ogah, O., Ugwu, O.O and Ehihia, L.U. (2012). Effects of Substituting Some Components of Broilers' Feed with Aqueous Extract of Fresh Leaves of Mucuna poggei. Journal of Biology and Life Science, 3, 243-253.

[12] Olaboro, G., Esonu, B. O., and Okot, M. W. (2001). Growth Depressing Factors in Mucuna flagellipes Leaves fed to Broiler Chicks. East African Agricultural and Forestry Journal, 57 (2): 103-110.

[13] Olomu, J.M. (1979). Poultry production in Nigeria: Proceedings of the first National Seminar on Poultry. A publication of Ahmadu Bello University, Zaria. 20-23.

[14] Tuleun, C.D., Carew, S.N. and Patrick, J.A. (2008). Fruit Characteristics and Chemical composition of some Varieties of Velvet beans (Mucuna spp) found in Benue State of Nigeria. African Journal of Biotechnology, 7, 2630-2670.

[15] Uchegbu, M. C., Okoli, C., Etuke, E.B., Anyanwu, C. E. and Esonu, B. O. (2002). Preliminary Studies on Mucuna flagellipes as Livestock Feed Ingredient: Proximate Composition. Proceeding of the $36^{\text {th }}$ Annual Conference of the Agriculture Society of Nigeria, Fed.Uni. of Tech. Owerri. October 20-24, pp 422-424. 